ISSN 1676-3742

\title{
Catolicismo, sociedade e teologia no Brasil Império
}

\author{
Catholicism, theology and society \\ in Brazil Empire
}

Ney de Souza

\section{Resumo}

O estudo da história da teologia é de extrema importância para se conhecer os imaginários e comportamentos que regem a eclesialidade. A partir desta constatação, o presente texto apresenta um estudo sobre a teologia no Brasil no tempo do império. Para compreender esta temática é necessário conhecer o contexto histórico deste período. Na primeira parte o texto apresenta a situação da sociedade civil e sua relação com a instituição religiosa. Na segunda parte são apresentados aspectos da teologia elaborada no período.

Palavras-chave: Teologia, império, Brasil, evangelização.

\begin{abstract}
The study of the history of theology is extremely important to know the imaginaries and conducts which govern the ecclesiality. From this finding, this article presents a study on theology in Brazil at the time of the empire. In order to understand this matter is necessary to know the historical context of this period. First this paper presents the situation of civil society and its relationship with the religious institution. The second part shows aspects of the theology developed during the period.
\end{abstract}

Keywords: Theology, empire, Brazil, evangelization. 


\section{Introdução}

A teologia é um discurso sobre Deus elaborado a partir de situações contextuais. A história da teologia católica no Brasil império (1822-1889) ${ }^{1}$ é a apresentação de uma pesquisa sobre as diversas maneiras e comportamentos como a fé foi vivenciada nesta primeira fase do Brasil independente de Portugal sob o regime político monarquista. Este estudo apresenta a construção de uma teologia que emerge neste importante período da formação da sociedade brasileira. $\mathrm{O}$ autor da pesquisa reconhece a importância e relevância dos discursos das outras denominações religiosas aceitas somente, pela Constituição civil de 1824, em seu culto doméstico. Contudo, aqui será estudada a teologia católica. Ressalta-se ainda a fundamental importância da auto compreensão da Instituição católica nos mais variados períodos de sua história. A partir desta auto compreensão se desdobram os imaginários e as práticas de fé da população de fiéis. Tendo por base esses elementos é que será apresentada a reflexão sobre alguns aspectos da história da teologia católica no Brasil império.

O texto é composto de duas partes que se entrelaçam. A primeira é a apresentação do contexto histórico religioso do Brasil imperial. A segunda parte terá como protagonista a teologia do período.

\section{Situação do catolicismo no Brasil Império}

\section{E o Padroado continua...}

As estruturas fundamentais da Instituição católica no Brasil não mudaram com a independência ${ }^{2}$. Estas estruturas travaram por um determinado período a grande batalha diplomática com a Santa Sé para o reconhecimento civil do novo Estado e a sua relação diplomática com o governo pontifício. Até o momento da independência, a Santa Sé não teve necessidade de pensar num sistema de relações distinto do Padroado ${ }^{3}$. Através deste instrumental se controlava a administração e o desenvolvimento de assuntos eclesiásticos. $\mathrm{O}$

\footnotetext{
${ }^{1}$ Este artigo faz parte do texto elaborado como Pós-doutorado em Teologia na PUC RJ sob a orientação do prof. Dr. Mario de França Miranda.

${ }^{2}$ SOUZA, N. "Um retrato do catolicismo no Brasil na época da independência", in ID. Temas de teologia latino-americana. São Paulo: Paulinas, 2007, 147-165.

${ }^{3}$ Cf. SOUZA, N. "Os caminhos do Padroado na evangelização do Brasil”, REB 247 (2002) 683-694.
} 
padroado era este instrumento concedido pela Santa Sé como privilégio aos reis de Portugal no início da colonização.

Portugal reconheceu oficialmente a independência do Brasil a 28 de agosto de 1825. A Santa Sé, por sua vez, deu o seu reconhecimento no dia 23 de janeiro de $1826^{4}$. O papa Leão XII reconheceu D. Pedro I como imperador do Brasil e prometeu confirmar os bispos para as dioceses vacantes. Assim, continuaria o Padroado no Brasil e somente no Brasil, pois nos Estados que nasceram na América Latina, colonizados pela Espanha, não havia mais Padroado e sim a Concordata ${ }^{5}$. A Igreja, portanto, continuou sob a tutela do Estado $^{6}$. A situação do Padroado no Império terá dois momentos de grande importância: o primeiro de 1826 até o inicio do Segundo Reinado em 1840; o segundo vai do Segundo Reinado até a Proclamação da República (1889). Neste período se verificará uma substancial transformação nas relações Igreja e Estado, principalmente no que é o pensamento do catolicismo em relação às suas atribuições no que se refere aos negócios eclesiásticos. Evidentemente tudo será embalado por uma teologia que será apresentada mais a frente.

$\mathrm{Na}$ Constituição Civil Imperial (1824), o catolicismo foi declarado como religião de Estado, tendo assim um caráter oficial e quase exclusivista. Afirma o artigo número 5: "A Religião Católica Apostólica Romana continuará a ser a religião do Império. Todas as outras religiões serão permitidas com seu culto domestico ou particular, em casas para isso destinadas, sem forma alguma exterior de templo"'.

É de suma importância frisar que este dispositivo da Carta de 1824 é continuidade do processo histórico iniciado no século XVI com a conquista e catequização do Brasil. Toda a vida social é profundamente marcada pela religião católica. As festas e comemorações, mesmo as cívicas, assumiam feições religiosas. Não se entendia a realidade sem uma explicita referência ao transcendente e à Igreja católica, esta última vista como representação visível da divindade. Desenvolve-se nos três primeiros séculos, de presença portuguesa, um catolicismo barroco, festivo, triunfalista e nacionalista. A religião faz parte da vida, tanto nas suas dimensões públicas e oficiais, quanto

\footnotetext{
${ }^{4}$ ANRJ Arquivo Nacional do Rio de Janeiro Coleção Eclesiástica, Caixa 946, doc. 12.

${ }^{5}$ GUTIERREZ, A. La Iglesia en Latinoamerica: entre la utopia y la realidad. Roma: PUG, 1996, pp. 159-178.

${ }^{6}$ SCAMPINI, J. A liberdade religiosa nas constituições brasileiras; estudo filosófico-jurídico comparado. Petrópolis: Vozes, 1978, p. 20.

${ }^{7}$ Disponível em: http://ww.planalto.gov.br/ccivil_03/constituicao. Acesso 08/05/2013.
} 
nas domésticas e pessoais, de muito Deus e pouco padre, muito céu e pouca Igreja, muita prece e pouca missa. Neste tipo de cristandade, as esferas civis e eclesiásticas praticamente se identificam, e o cidadão é quase obrigatoriamente cristão. Há uma sacralização das estruturas sociais e políticas. Estaria neste ponto a raiz do processo da dessacralização do sagrado.

É a partir desta realidade que se analisa a expressão 'continuará' do artigo 5 da Constituição de 1824 . O termo ali empregado revela a herança histórica de matriz católica lusitana. Afirma-se assim, que a religião católica é a da maioria dos brasileiros e, por consequência pode ser a religião considerada oficial e nacional, com direito a uma proteção oficial. O esquema utilizado é o da cristandade que idealiza a mútua harmonia e necessária união entre os dois poderes: temporal e espiritual. Apesar dos princípios liberais difundidos no Brasil a ideia de cristandade permanece. Aqui não se trata de uma cristandade de perfil medieval.

A configuração que ora se apresenta é a cristandade nacional. O poder eclesiástico não é superior ao civil. Através dos direitos de padroado concedidos na colônia e novamente no império são direitos, portanto, adquiridos pelo rei e agora pelo imperador. Direitos dentro da doutrina regalista de interferência, com direito, do Estado nos negócios eclesiásticos (nomear bispos e prover outras funções eclesiásticas; conceder ou negar o beneplácito régio aos decretos papais antes de serem divulgados no Brasil). A evolução desta doutrina levará ao surgimento de uma Igreja de caráter nacional e, portanto uma ameaça de cisma. $\mathrm{O}$ catolicismo no Brasil Império, no seu primeiro período, terá um reconhecimento do papa como chefe honorífico, mas sem uma efetiva autoridade sobre a Igreja Nacional. Na Constituição de 1824 são encontrados diversos elementos dessas tendências regalistas e galicanas. A Constituição reconhece implicitamente os vínculos da Igreja católica no Brasil com a Santa Sé. No entanto, referindo-se à pessoa do Imperador, o mesmo documento concede-lhe amplos poderes sobre o catolicismo tido como nacional. O que se constata é que a Igreja católica é tratada como um departamento da administração civil e deve ser útil para o Estado. O clero faz parte do funcionalismo público e é pago (quando é) pelos cofres estatais. "Tal fenômeno não deixaria de influir na mentalidade dos sacerdotes e em suas atividades pastorais, bloqueando a capacidade de iniciativas e sujeitando-os à rotina de trabalhos oficiais e sistematicamente controlados pelo Estado"». Essa situação ao longo do Império se revelará ambígua para o catolicismo. Uma nova

${ }^{8}$ LUSTOSA, O. de F. Reformistas na Igreja do Brasil império São Paulo: USP, 1977, p. 19. 
mentalidade teológica levará a grandes divergências entre o poder espiritual e o poder temporal, chegando a consequências de extrema dificuldade para os dois poderes, como a questão religiosa (1872-1874), levando a prisão dois bispos. É evidente, como afirmou Sérgio Miceli, o período em foco presenciou o processo de construção institucional da Igreja católica brasileira, de sua própria consciência e sua relação com a sociedade ${ }^{9}$. O processo culminará com a separação entre a Igreja e o Estado na Constituição republicana de 1891.

\section{Catolicismo no período da abdicação de D. Pedro I e das Regências}

Problemas dos mais variados tornam inviável a permanência de D. Pedro I à frente do governo brasileiro. O imperador fica cada vez mais isolado. A oposição cresce, encontrando na imprensa um instrumento adequado para expressar-se publicamente. Aumentam as dívidas do país junto aos bancos ingleses, fazendo com que a situação financeira se torne extremamente precária $^{10}$. Os acontecimentos internos de Portugal, decorrentes da sucessão de D. João VI, que morreu em 1826, envolvem diretamente a pessoa de D. Pedro I. Suas preferências pelos portugueses residentes no Brasil são conhecidas e asperamente criticadas pelos brasileiros. A retirada do monarca apresenta-se como inevitável. A 7 de abril de 1831 ele assina sua abdicação em favor do filho de cinco anos, D. Pedro de Alcântara. Após sua partida é instituída uma Regência pelo fato de o único herdeiro do trono ser menor de idade.

Os nove anos de Regência (1831-1840) ${ }^{11}$, provisória, trina e uma, constituem um período de forte turbulência com diversas revoltas provinciais de grande alcance. Um dos períodos mais violentos da história do Brasil. Tendências federalistas e separatistas marcam o cenário político. Seus integrantes mal articulados entre si acabam sendo esmagados pelo poder central. Em muitos desses movimentos aparecem reivindicações sociais. As rebeliões tomavam um caráter popular e manifestavam uma violência contrária àquela que restringia a uma pequena parcela da população a propriedade, $o$ reconhecimento social e os direitos de expressão, participação e organização

\footnotetext{
${ }^{9}$ MICELI, S. A elite eclesiástica brasileira. Rio de Janeiro: Bertrand do Brasil, 1988.

${ }^{10}$ NEVES, L. B. P. das. "Abdicação", in VAINFAS, R. (dir.). Dicionário do Brasil imperial (18221889) Rio de Janeiro: Objetiva, 2002, pp. 12-14.

${ }^{11}$ LYRA, M. de L. V. O Império em construção: Primeiro Reinado e Regências. São Paulo: Atual Editora, 2000.
} 
política ${ }^{12}$. Alguns autores, afirma Rubert, "parecem ter subestimado o periodo da Regência nas suas relações com a Santa Sé e o perigo de um rompimento com a Igreja. Não existia tal desejo, mas, na prática, defendendo teorias febronianas e galicanas, chegou-se quase ao rompimento"'13.

Uma das figuras marcantes e polêmica desse período regencial é o padre Diogo Antônio Feijó (1784-1843), primeiro como Ministro da Justiça na Regência Trina Permanente (17/06/1831 a 12/10/1835) e depois como Regente Uno (12/10/1835 a 18/09/1837). Monarquista liberal fora deputado brasileiro às Cortes em Portugal. Feijó é uma figura contraditória que governa em meio a revoluções, acusado de autoritário e 'ministro de Satanás' ou 'sedutor e alcoviteiro'. Acaba se isolando no governo e, finalmente, não resta outro caminho a não ser a renúncia. Dando seu apoio à Revolução Liberal de 1842 , é preso, desterrado, mas depois absolvido ${ }^{14}$. Integrou como deputado a primeira Assembleia Geral Legislativa, na qual defendeu, em 1827, a proposta de abolição do celibato clerical no Brasil. Sua postura baseava-se no argumento de que se tratava de medida que, visando o bem da religião católica, contribuiria para a regeneração da conduta de muitos padres que viviam no concubinato. O que é importante, neste ponto, para a composição deste estudo sobre a teologia no império brasileiro é a percepção que estes pensamentos, projetos e práticas estão alicerçados na doutrina galicana e febroniana ${ }^{15}$ preconizando, assim uma igreja nacional.

Um golpe de Estado em meados de 1840 conclui a Campanha da Maioridade de D. Pedro $\mathrm{II}^{16}$, que então contava com apenas 14 anos. Os partidários da maioridade já viam no restabelecimento da plena soberania imperial o fim da crise de autoridade que, segundo eles, fora a causa principal da agitação e anarquia das Regências. Embora promovida por liberais, em longo prazo, a vitória da maioridade, oficializada a 23 de julho de 1840, caberia aos conservadores, porta-vozes dos verdadeiros donos do poder. Se para a sociedade civil tem início outro e importante momento da política nacional, para a Igreja católica não será diferente.

\footnotetext{
${ }^{12}$ FAUSTO, B. História do Brasil. São Paulo: Edusp, 1999.

${ }^{13}$ RUBERT, A. A Igreja no Brasil. Galicanismo imperial (1822-1889). Santa Maria: Pallotti, 1993, p. 31.

${ }^{14}$ RICCI, M. As assombrações de um padre regente. Campinas: Unicamp, 2005, p. 57.

${ }^{15}$ Para um estudo sobre estas doutrinas ANDRESEN, C.; DENZLER, G. Dizionario storico del Cristianesimo. Milano: Edizioni Paoline, 1992 pp. 293-294; 306-307.

${ }^{16}$ ABREU, C. "Fases do Segundo Império", in Instituto histórico e geográfico brasileiro. Contribuições para a biografia de D. Pedro II. Rio de Janeiro, tomo especial, 1925, parte 2, pp. 432-445.
} 
No início do século XIX com os desdobramentos revolucionários da Revolução francesa (1789-1799), o catolicismo começa a sentir sua perda de influência na sociedade ocidental. A Santa Sé reage de forma bastante firme. Opõe-se, por um lado, às novas perspectivas de vida apresentadas pelo progresso científico, a Igreja procura restaurar os antigos valores da sociedade medieval, inclusive os princípios filosóficos e teológicos, apregoando a necessidade de subordinação do homem à ordem sobrenatural. A pregação é voltada para a humildade e obediência diante das diretrizes emanadas pela hierarquia eclesiástica. Baluartes deste período são os papas Gregório XVI (1831-1846) e Pio IX (1846-1878). O primeiro em sua primeira encíclica Mirari vos (1832) exige um empenho de todos contra os inimigos da Igreja. Reafirma a autoridade do papa, o valor do celibato, a indissolubilidade do matrimônio. Condena o indiferentismo, o racionalismo, as liberdades de consciência, de imprensa e pensamento, assim como a separação Igreja-Estado. Já o segundo defende a fé e esta defesa é feita em detrimento da confiança do homem no valor da ciência, como aparece claramente no anexo Silabus de sua encíclica Quanta Cura (1864) ${ }^{17}$. Neste documento condena-se a proclamada independência do homem com relação aos ditames da religião católica. Condenava marxismo, socialismo, naturalismo, racionalismo e as sociedades secretas, inclusive a maçonaria.

Essas ideias católicas foram introduzidas no Brasil ao longo do período Imperial. Período em que o imperador nomeava os bispos de tendência conservadora, sintonizados com a ordem social vigente. O catolicismo procura o apoio do Estado a fim de prosseguir com seu próprio projeto de reforma católica, inspirada nas diretrizes da Cúria Romana. A Igreja estava disposta a implantar o modelo eclesial tridentino no Brasil, com a colaboração da Santa Sé. A reestruturação eclesiástica, liderada pela hierarquia, ficou conhecida como o movimento dos bispos reformadores. Um dos objetivos da atuação episcopal era frear o dinamismo político que a ideologia liberal havia gerado numa parcela significativa do clero. Desde os primeiros anos do Brasil independente, houve reação a um tipo de Igreja regalista ou submissa ao poder imperial. Era uma postura ultramontana preocupada com a formação do clero e com a evangelização dos fiéis dentro das diretrizes do Concílio de Trento

${ }_{17}$ Tradução dos documentos citados: Documentos da Igreja. Gregório XVI e Pio IX. São Paulo: Paulus, 1999 pp. 25-42; 248-275. 
(1545-1563). Lentamente essa ação encontrará espaço político para se manifestar, como fizeram alguns bispos em diferentes dioceses do país.

A ação dos Bispos reformadores

Desde o período colonial houve tentativas de implantação da reforma tridentina no Brasil. O fato que constitui melhor essa tentativa foi o Sínodo da Bahia de 1707 ${ }^{18}$; convocado pelo arcebispo D. Sebastião Monteiro da Vide, que resultou nas Constituições Primeiras do Arcebispado da Bahia ${ }^{19}$. Todavia sua consolidação definitiva somente acontecerá a partir da segunda metade do século XIX.

A partir de 1827 é arcebispo da Bahia D. Romualdo Antônio de Seixas ${ }^{20}$. Será o arcebispo até o ano de 1860. Inicialmente era regalista moderado, mas depois aderiu plenamente ao movimento da reforma tridentina - 'romana'. Foi amigo próximo de D. Pedro II que muito o admirava e passava algumas horas com ele em elevações literárias e culturais. No entanto, a reforma se efetivará, sobretudo em Minas Gerais e em São Paulo através da ação de seus bispos: D. Antônio Ferreira Viçoso e D. Antônio Joaquim de Melo.

O padre lazarista e português de nascimento, Antônio Ferreira Viçoso, foi nomeado bispo de Mariana em 1844. O representante pontifício o chamou "o ótimo entre os bons" 21 . Iniciou uma ampla reforma da própria diocese. Este bispo será o propulsor da revitalização em outras regiões do país, com bispos formados por ele: D. Luís Antônio dos Santos, em Fortaleza (1861-1881); D. Pedro Maria de Lacerda, no Rio de Janeiro (1869-1890) o representante pontifício afirmava que este era um dos melhores do clero brasileiro ${ }^{22}$; D. João Antônio dos Santos, em Diamantina (1863-1905). D. Viçoso ordenou 276 sacerdotes durante seu episcopado. Ultramontano e tridentino combateu o que considerava abusos da piedade popular, sobretudo as festas que resultavam em licenciosidades e pecados. Foi um grande incentivador da devoção à Virgem Maria, introduzindo o mês de Maria nas paróquias de sua diocese.

\footnotetext{
${ }^{18}$ SOUZA, N. "Um panorama da Igreja católica no Brasil (1707-1808)", in Revista de Cultura Teológica 39 (2002) pp. 9-37.

${ }^{19}$ FEITLER, B.; SOUZA, E. S.. A Igreja no Brasil. Normas e práticas durante a vigência das Constituições Primeiras do Arcebispado da Bahia. São Paulo: Editora Unifesp, 2011, especialmente pp. 9-23.

${ }^{20}$ RUBERT, A. A Igreja no Brasil. Santa Maria: Editora Pallotti, 1993, pp. 48-53.

${ }^{21}$ ASV - Arquivo Secreto Vaticano, Nunciatura Brasil. Despacho 137, 24/08/1844.

${ }^{22}$ ASV Nunciatura do Brasil, Despacho 2273, fascículo 2, ff, 94-95.
} 
O apóstolo de Minas Gerais, como alguns o qualificam, foi um formador de quadros romanizados e, defensor da autoridade eclesiástica contra o regalismo, Recebeu o título nobiliárquico de conde da Conceição. Faleceu no dia 7 de julho de $1875^{23}$.

O padre paulista Antônio Joaquim de $\mathrm{Melo}^{24}$, escolhido para ser bispo de São Paulo (1852-1861), começou a reforma pelo clero. Para o clero baixou um regulamento de conduta. Depois outro para os ordenandos. O remédio, porém, seria a ereção do Seminário. Foi o que ele fez. Com numerosos sacrifícios e com a ajuda do governo e de benfeitores, em 9-11-1856, estabeleceu o Seminário Santo Inácio de Loiola, que o papa Pio IX o quis também de Maria Imaculada, entregando sua direção aos capuchinhos de Savóia. Isto exigiu do prelado muita coragem e decisão. No entanto, o que mais distinguiu o pastor foi suas assíduas e prolongadas visitas pastorais a todos os recantos da diocese $\mathrm{e}^{25}$. Era uma verdadeira missão. Indagava tudo. Quatro vezes percorreu em visita sua diocese. Não obstante tanto zelo e dedicação pastoral, D. Antônio Joaquim de Melo sofreu ataques do cabido e da imprensa, nomeadamente no Amigo da Religião. No entanto, ele continuou impávido no seu trabalho de reforma.

No final do período imperial entraram neste grande palco das transformações da reforma as figuras de D. Antônio de Macedo Costa, bispo do Pará (1861-1890) e D. Vital Maria Gonçalves de Oliveira, bispo de Olinda $(1872-1876)^{26}$. Os dois bispos entraram em grande conflito com o poder civil. Na superfície do conflito estava a jurisdição dos bispos que de 1872 a 1875, envolveu a imprensa e mobilizou considerável parcela da população. No entanto, nas profundezas, agitou uma série de tensões que envolviam a concepção e a prática da religião no Império, contribuindo decisivamente para abalar a Monarquia. No âmbito mais geral, a conhecida Questão Religiosa ${ }^{27}$ não pode ser compreendida sem referência à instituição do padroado no Brasil, e à posição da Santa Sé apresentadas anteriormente.

\footnotetext{
${ }^{23}$ CARVAlHO, J. G. V. “Aspectos da evangelização em Minas Gerais no século XIX”, in Temas de história da Igreja no Brasil. Viçosa: Folha de Viçosa, 1994, p. 35.

${ }^{24}$ AZZI, R. "Dom Antônio Joaquim de Melo, bispo de São Paulo (1851-1861), e o Movimento de Reforma Católica no século XIX”, in REB 35 (1975) p. 921.

${ }^{25}$ WERNET, A. A Igreja paulista no século XIX. São Paulo: Ática, 1987, pp. 118-143.

${ }^{26}$ ASV Nunciatura do Brasil, Despacho 3059 f. 160.

${ }^{27}$ AZEVEDO, F. “Os antecedentes históricos do conflito entre D. Vital e o regalismo brasileiro e a sua resolução ineficaz", in REB 247 (2008) pp. 91-126; BARROS, R. S. M de. "A questão religiosa”, in HOLANDA, S. B. de. História Geral da Civilização Brasileira. O Brasil monárquico. Tomo II vol. 6, Rio de Janeiro: Bertrand Brasil, 2004, pp. 392-423.
} 
O novo bispo de Olinda, D. Vital, foi formado no ambiente ultramontano, contra as ideias liberais e favorável à união com Roma, com o papa e suas orientações. A Santa Sé havia proibido a entrada de sacerdotes e outros membros eclesiásticos na maçonaria. D. Vital foi intransigente nesta orientação e quis organizar a sua diocese segundo estes princípios. Seguiu seu exemplo o bispo do Pará, D. Macedo Costa. Estas atitudes foram elogiadas por quase todos os bispos no Brasil. O conflito cresceu em março de 1872 quando D. Pedro Maria de Lacerda, bispo do Rio de Janeiro, suspendeu de ordens o padre José Luiz de Almeida Martins por proferir um discurso em estilo maçônico, já que era orador oficial da maçonaria. Em fins de junho uma circular secreta de D. Vital proibiu a participação de eclesiásticos em qualquer cerimônia maçônica. Em represália, uma loja convocou a celebração, para 21 de julho da mais 'auspiciosa data da humanidade', aquela em que fora suprimida, em 1773, pelo papa Clemente XIV, 'a nociva congregação dos jesuítas'. A partir de agosto, a tensão aumentou com as respostas dos maçons aos artigos publicados no jornal $A$ União, criado por D. Vital. Artigos que criticavam a liberdade de culto e de pensamento, a separação Igreja e Estado e colocavam a Igreja acima do poder civil, ao insistir em que as leis dos homens não podiam ser distinguidas das leis de Deus. Quando o jornal maçônico ousou publicar artigos de um protestante discutindo a perpétua virgindade de Nossa Senhora, o prelado lançou um interdito sobre duas capelas de irmandades que se recusavam a expulsar os confrades maçons, passando a enfrentar uma campanha de difamação pessoal, que o acusava de frequentar, com demasiada assiduidade, os conventos femininos. Após um comício de desagravo, a tipografia dos jesuítas que imprimia o jornal do bispo, foi saqueada e um sacerdote morto com uma facada ${ }^{28}$.

Devido a este último acontecimento, a Coroa procurou conter D. Vital, ordenando-lhe que levantasse o interdito que lançara sobre as irmandades. O prelado recusou-se argumentando que seguia as diretrizes do papa. Essas diretrizes, no entanto, dependiam do beneplácito, instituição que dava ao Imperador o direito de vetar as determinações vindas do Vaticano. Em outras palavras, todas as determinações do papa só passavam a ter validade no Brasil depois do placet, isto é, depois da aprovação explícita do Imperador. Os adversários aproveitaram esta normativa para considerar as diretrizes pontifícias como intervenções nos assuntos do Brasil e diversos deputados apresentaram requerimentos para que o governo cortasse relações com a Santa Sé. A

${ }^{28}$ NEVES, G. P. das. "Questão religiosa”, in VAINFAS, R. (dir.). Dicionário do Brasil império (1822-1889). Rio de Janeiro: Objetiva, 2002, pp. 608-611. 
Questão religiosa tornava-se uma questão nacional e internacional. O bispo foi indiciado pelo Supremo Tribunal de Justiça. D. Vital foi preso em 2 de janeiro de 1874 e transferido para o Rio de Janeiro, onde foi julgado a partir de fevereiro, juntamente com D. Antônio de Macedo Costa, bispo do Pará, que havia procedido da mesma forma. Ambos foram condenados a pena de 4 anos com trabalhos forçados, causando grande comoção nacional.

Em 1875 a Questão foi encerrada com a comutação da pena pelo imperador e a anistia concedida aos bispos. Contudo, a Questão religiosa acirrou a intransigência da alta hierarquia da Igreja, levando-a a assumir uma atitude ambígua em relação ao Estado que implicava, ao mesmo tempo, a oposição a certas medidas de caráter secular e a reivindicação de conservar o lugar privilegiado, no plano espiritual, que sempre detivera junto ao poder. De outro lado, porém, quebrou o encanto da função monárquica. Para as mentalidades secularizadas que defendiam o progresso e a atuação do governo no episódio revelou-se fraca e movida unicamente pelos interesses políticos do gabinete conservador. Para os fiéis tocados pelo ultramontanismo, majoritariamente urbanos e alfabetizados, a prisão dos bispos indicou o caráter arbitrário das instituições, distanciando-os do regime. Para a grande massa da população, ainda presa à religiosidade antiga, tudo aquilo não passara de uma impiedade. De todos os espíritos, retirava-se do cetro de D. Pedro II a aura mágica, que lhe tinha assegurado até então o exercício do poder.

A reforma promovida por estes bispos ultramontanos foi preferencialmente a do clero. O objetivo era ter um padre douto e santo, de conduta reta e grave, um digno representante da ordem espiritual e inteiramente voltado para as coisas do alto. Uma constante preocupação é a estrita observância do celibato. Formado assim seria o ideal para a sua missão de evangelizar uma população de fiéis que vivenciava uma religiosidade popular classificada como fanatismo e superstição. A fé popular é vista como uma deturpação da verdadeira religião que só poderia ser encontrada no culto oficial que obedece às normas romanas. Em lugar das antigas devoções, os bispos apoiados pelas Congregações religiosas, promovem novas devoções alinhadas à doutrina oficial. Necessário ressaltar que não é possível generalizar a situação problemática de grande parte do clero, pois ao contrário poderia se pensar que somente depois da reforma é que os padres entraram para a reta via ${ }^{29}$.

${ }^{29}$ OLIVEIRA, P. A. R. et alii. Evangelização e comportamento religioso popular. Petrópolis: Vozes, 1978, p. 14. 


\section{Aspectos da teologia católica no Império}

Neste contexto apresentado anteriormente o catolicismo afirma-se no Brasil como sendo uma sociedade hierárquica perfeita. Somente dentro dele, na fidelidade à sua doutrina e a prática sacramental, está a salvação. O discurso sobre Deus nesta realidade é importado e, assim, os religiosos darão ênfase especial à teologia do mérito, que passa a substituir a teologia do desterro, típica do período colonial. A devoção aos santos assume características de maior vinculação à hierarquia católica, emergindo como grande devoção do período o culto ao Sagrado Coração de Jesus.

Durante o período colonial o catolicismo viveu em total dependência do poder da Coroa portuguesa. Essa situação continua no Império quando este, através da Constituição de 1824, afirma a fé católica como religião oficial do Estado brasileiro e, em seguida, a concessão dos direitos de Padroado por parte da Santa Sé ao Imperador.

No entanto, a hierarquia católica reage com energia devido à atuação regalista e galicana do Império. Com total apoio da Santa Sé o episcopado brasileiro decide implantar no Brasil a concepção tridentina da Igreja.

Nesse sentido a concepção unitária de sociedade católica não é mais aceita. O que se enfatiza orientando a população a seguir é a mentalidade de duas sociedades perfeitas e distintas entre si: de um lado o Estado ou sociedade temporal/civil, de outro lado a Igreja ou sociedade eclesiástica/espiritual. Ao Estado compete cuidar dos interesses temporais, dos aspectos políticos e socioeconômicos; à Igreja fica reservada a missão de ocupar-se da vida espiritual das pessoas, dos aspectos religiosos. O Estado cuida do corpo e a Igreja zela da alma. Essa ação espiritual seria desenvolvida com plena liberdade e autonomia por parte da Igreja, é por isso que a instituição religiosa lutará. O episcopado não se considera mais dependente do poder civil, mas como responsável direto da orientação da atividade pastoral. É uma elaboração teológica voltada quase unicamente à esfera espiritual.

Nesse momento a teologia católica enfatiza o caráter dos bispos como príncipes eclesiásticos, membros de uma hierarquia sagrada da qual o papa é o chefe supremo. O poder deste episcopado é fortalecido na medida em que recebe a chancela da Santa Sé. Os bispos passam a defender seus direitos exclusivos de dirigir os negócios eclesiásticos da Igreja católica no Brasil. A Igreja católica, como afirma Riolando Azzi, é a barca de salvação, cujo 
legítimo timoneiro é o papa ${ }^{30}$. Será exatamente como delegado do poder pontifício, que o episcopado exercerá sua missão religiosa.

No exercício de seu ministério pastoral de cunho salvífico, o episcopado conta com a colaboração do clero. É neste sentido que os bispos se empenham na reforma do clero no Brasil. O grande trabalho do episcopado era transformar um clero com alma política e amasiados, em sacerdotes piedosos e celibatários. Esse desejo era também do governo brasileiro. As forças governamentais incentivavam os bispos a reconduzir o clero ao recinto das Igrejas, reduzindo sua atividade ao altar, ao púlpito e ao confessionário. A participação do clero liberal nas lutas políticas e sociais constituía para o governo um obstáculo à monarquia que vivia dentro do sistema latifundiário escravocrata. O imperador Pedro II foi bastante cioso na escolha de homens piedosos para o episcopado, mas que eram ao mesmo tempo de mentalidade conservadora e antiliberal ${ }^{31}$.

No decorrer dos anos os bispos foram percebendo o seu crescimento no que se refere ao poder espiritual, assim chegaram a negar qualquer dependência do poder temporal. Esta postura deu origem ao importante conflito entre Estado e Igreja, conhecido como Questão Religiosa (1872-1875), apresentada no item anterior. É interessante frisar que mesmo pregando a independência de ação como sendo fundamental, a igreja continuava a defender a doutrina da colaboração entre os dois poderes. Em outras palavras, pregava a independência no pensar e na ação, mas desejava a continuidade da união entre Trono e Altar, para a manutenção e defesa da ordem social vigente.

O que se verificará no Segundo Reinado (1840-1889) é uma participação nula do clero nos movimentos pela abolição da escravidão e pelo advento do regime republicano, liderados pela burguesia urbana liberal. A Igreja Católica mantem-se à sombra do Trono, sendo um de seus sustentáculos. Advoga para si o caráter de aliada do poder estabelecido sem questionar os seus méritos. Neste período o clero estava mais preocupado com os méritos para o céu do que com os problemas concretos da população na terra. O abolicionista Joaquim Nabuco afirmava que "eu tinha sempre lastimado a neutralidade do clero perante a escravidão, o indiferentismo do seu contato com ela" 32 .

\footnotetext{
${ }^{30}$ AZZI, R. "A teologia no Brasil. Considerações históricas”, in História da Teologia na América Latina. São Paulo: Paulinas, 1985. p. 31.

${ }^{31}$ AZZI, R. "D. Pedro II e a reforma do clero no Brasil", In Revista do Instituto Histórico e geográfico do Brasil, 1978.

${ }^{32}$ NABUCO, J. Minha formação. Rio de Janeiro: Coleção documentos do Brasil nº 90, 1957.
} 


\section{Uma teologia espiritual}

A mentalidade religiosa que se afirmará no Império é de uma visão puramente espiritual do mundo. Assumindo grande importância neste período um discurso sobre Deus no que se refere ao mérito. Uma teologia espiritual que passou a vigorar na Igreja a partir do século XVI, especialmente com os exercícios espirituais de Inácio de Loyola. Esse tipo de mentalidade e pratica se adequou perfeitamente ao espírito tridentino. Esta teologia é uma resposta católica à mentalidade da burguesia que começava a se afirmar a partir do mercantilismo introduzido pela Revolução Comercial.

A burguesia tem como característica principal sua atividade econômica, tendo sempre em vista o lucro. O êxito comercial é medido em termos de ganhos e perdas. Ao mesmo tempo os católicos são acusados de não valorizarem o mundo, considerando a terra como um verdadeiro exílio ou desterro. Em resposta, a teologia ascética passa a enfatizar que existem dois tipos de atividade no mundo: a atividade política e econômica, de significado passageiro, e a atividade espiritual, de valor eterno, através da qual se obtém os verdadeiros lucros, os méritos para o céu. Neste sentido, a terra deixa de ser um local de exílio e passa a ser um lugar de prova, onde mediante obras espirituais, as pessoas devem procurar merecer o prêmio eterno. Portanto, os valores terrenos continuam destituídos de sentido. $\mathrm{O}$ único valor verdadeiro é a salvação. A salvação torna-se uma decorrência dos méritos adquiridos na terra. Os pecados cometidos passam a constituir o verdadeiro obstáculo para o prêmio. Daí a importância do recurso à mediação sacramental da confissão para restabelecer o equilíbrio da balança do juízo.

No século XIX essa teologia é de grande aceitação por parte das camadas médias urbanas. Essa população é atendida através das paróquias e das atividades dos colégios. O clero é formado, neste período, dentro dessa nova visão religiosa do mundo. Nos seminários a prática dos exames de consciência e o reforço dos exercícios espirituais constituem a parte central da vida dos futuros clérigos. A pastoral é também orientada na multiplicação de obras religiosas. As missões populares são promovidas sob o significativo lema: salva a tua alma.

A vida de fé é medida pela quantidade de obras espirituais realizadas. Assim são feitas estatísticas sobre o número de confissões, comunhões, batizados e casamentos. Dados elevados atestam o aumento de méritos para o céu. Para uma exemplificação interessante da teologia do mérito cita-se o ato de contrição que deve preceder a confissão sacramental: "Pesa-me, Senhor, por 
ter perdido o céu e merecido o inferno". É exatamente numa perspectiva de salvação eterna que a vida presente tem algum sentido.

O que fica evidente pesquisando sobre este período é a substituição expressiva das antigas devoções populares típicas da cultura lusa, por novas devoções trazidas por religiosos europeus. Em pouco tempo os santos vão sendo substituídos pelas novas devoções trazidas por missionários vindos a pedido dos bispos para reforçar o movimento de reforma. Eram substituídas as devoções e também o modo de cultuá-las. Antes eram muitas festas, procissões, romarias, depois a ênfase dada é na prática sacramental, considerada a autentica expressão de fé. O catolicismo popular, nesta teologia, passa a ter um vínculo direto com a instituição clerical. No meio urbano há uma grande aceitação, diferentemente do meio rural. No sertão perdura a devoção tradicional, as capelinhas à beira da estrada são ainda um marco expressivo.

No Brasil rural a assistência paroquial era dificultada pelas distâncias, pela própria ausência de padres. No Brasil urbano do século XIX as pessoas foram assistidas com alguma regularidade pelos padres, principalmente na hora da morte ${ }^{33}$.

No meio urbano a devoção ao Sagrado Coração de Jesus, incentivada pelos jesuítas, cresce através da associação do Apostolado da Oração. A devoção ao Sagrado Coração de Jesus reflete a nova visão teológica a respeito da sociedade deste período. Importante recordar que o século XIX é marcado pelo ultramontanismo e pela ação antiliberal por parte dos católicos. A devoção expressa de maneira fundamental uma visão de mundo: Jesus é o prisioneiro do sacrário, e os seus devotos devem refugiar-se aos seus pés para reparar os pecados que os maus e os inimigos da fé estão cometendo. A devoção é expressa através das comunhões nas nove primeiras sextas-feiras, onde se ressalta a tônica reparadora. Reparar o espírito liberal de clérigos e católicos, considerados maus cristãos. Existe uma larga diferença entre a devoção ao Bom Jesus (símbolo sofredor em que o povo se identificava) de caráter lusitano e a nova devoção franco-italiana do Coração de Jesus (símbolo da Igreja como poder espiritual). Aqui se expressa cada vez mais o poder da Santa Sé no Brasil diante do Império, um catolicismo cada vez mais romanizado.

Hugo Fragoso apresenta três aspectos dessa teologia de inspiração ultramontana. Primeiramente, o fato de estar diretamente a serviço da formação do

\footnotetext{
${ }^{33}$ REIS, J. J. "O cotidiano da morte no Brasil oitocentista”, in ALENCASTRO, L. F. História da vida privada no Brasil. Império: a corte e a modernidade nacional. Vol. 2. São Paulo: Companhia das Letras, 1997, p. 106.
} 
clero, sendo uma sistematização dos dados teológicos e do magistério eclesiástico. Trata-se da teologia repetitiva, sem inovação. O estudo da teologia passa a ser exclusividade dos clérigos. Em segundo lugar, o autor destaca seu caráter marcadamente apologético, sendo destinada especificamente à defesa da Igreja.

$\mathrm{O}$ terceiro aspecto é apresentado nestes termos:

Outra característica de nossa teologia era que ela estava a serviço da 'ortodoxia' romana. O Segundo Império é justamente o período da tomada de consciência 'romana' de nossa Igreja, e consequentemente tomada de posição ao lado da 'ortodoxia', emanada do ensino do supremo magistério eclesiástico. Nossos professores de teologia, que foram estudar em Roma ou na França, voltaram mais ligados a este magistério e à linha de orientação chamada 'ultramontanismo'. Mas, sobretudo os lazaristas franceses eram instrumentos importantes dessa orientação de nossa teologia. É de lembrar-se que 'ortodoxia' então significava, de modo especial, oposição ao jansenismo, ao galicanismo, ao regalismo, ao liberalismo. E os lazaristas eram os grandes opositores dessas orientações teológicas que se opunham ao 'ultramontanismo"34.

Aqui, portanto, reside a preocupação de definir claramente os limites da ortodoxia romana. Coloca-se ênfase no aspecto da unicidade da verdade religiosa, que se encontra exclusivamente na fé católica. À medida que se fortalecia a teologia de raiz ultramontana, e a hierarquia se tornavam intransigente, diminuía o espaço para que pudessem florescer dentro do âmbito do pensamento católico correntes impregnadas pelo pensamento liberal e socialista.

\section{Considerações finais}

O catolicismo da Reforma no Brasil conseguiu implantar um novo modelo de Igreja como sociedade perfeita, de inspiração tridentina. Além das novas devoções o episcopado procura promover a doutrina através de catecismos. A ênfase da reforma católica é preponderantemente clerical. $\mathrm{O}$ episcopado preocupou-se muito mais em trazer os fiéis para dentro da estrutura eclesiástica do que em colaborar efetivamente na defesa de seus direitos na sociedade. O catolicismo deslocava-se do leigo para o bispo, da religião familiar para a religião do templo, das rezas para a missa, do terço para os sacra-

${ }^{34}$ História da Igreja no Brasil. Petrópolis: Vozes, 1980, tomo II/2, p. 198. 
mentos. Assim, este deslocamento privilegiou o poder sacerdotal e esvaziou as funções do leigo na vida da Igreja. Passa-se da religião comprometida com o debate político e social da nação para uma religião voltada para o espiritual e para o distanciamento das realidades terrenas ${ }^{35}$. Eis, portanto, uma teologia elaborada a partir do contexto do 'céu'. Mesmo não alcançando neste período realizar inteiramente a reforma pretendida e tendo que esperar o regime republicano para ganhar autonomia e ação, o catolicismo, ao longo do período imperial, conseguiu ao menos estabelecer suas bases institucionais.

\section{Referências bibliográficas}

AZZI, R. "A teologia no Brasil. Considerações históricas", in Pontifícia Faculdade de Teologia Nossa Senhora da Assunção. História da Teologia na América Latina. São Paulo: Paulinas, 1985.

- A teologia católica na formação da sociedade colonial brasileira. Petrópolis: Vozes, 2004.

. “As romarias no Brasil”, in Revista de Cultura Vozes 4 (1979) 281-282.

A Igreja católica na formação da Sociedade brasileira. Aparecida: Santuário, 2008.

AZZI, R. - GRIJP, K. van der. História da Igreja no Brasil. Ensaio de interpretação a partir do povo. Tomo II/3-2, terceira época - 1930 1964. Petrópolis: Vozes, 2008.

BRUNEAU. T. C. O catolicismo brasileiro em época de transição. São Paulo: Loyola, 1974.

MARTINA, G. La Chiesa nell'età Del liberalismo. Brescia: Morcelliana, 1991.

MONTENEGRO, J. A. de S. Evolução do catolicismo no Brasil. Petrópolis: Vozes, 1972.

SERBIN, K. P. Padres, celibato e conflito social. Uma história da Igreja Católica no Brasil. São Paulo: Companhia das Letras, 2008.

${ }^{35}$ BEOZZO, J. O. “Irmandades, Santuários, Capelinhas de Beira de Estrada”, in REB 37 (1977) p. 748. 
SOUZA, N. "Os caminhos do Padroado na evangelização do Brasil", in REB 247 (2002) 683-694.

WERNET, A. A igreja paulista no século XIX. São Paulo: Ática, 1987.

Ney de Souza Doutor em História Eclesiástica pela PUG (Roma), registro USP Professor na PUC-SP São Paulo/SP - Brasil E-mail:nsouza@pucsp.br

Recebido em: 09/01/14 Aprovado em: 04/02/14 